\title{
СОЦІАЛЬНА ВІДПОВІДАЛЬНІСТЬ ЯК СКЛАДОВА ІННОВАЦІЙНОГО ОСВІТНЬОГО ПРОЦЕСУ ТА ЗАБЕЗПЕЧЕННЯ КОНКУРЕНТОСПРОМОЖНОСТІ ЗАКЛАДУ ВИЩОЇ ОСВІТИ
}

\author{
Кирчата І. М., канд. екон. наук, доцент \\ Шершенюк О. М., канд. екон. наук, доцент \\ Харківський національний автомобільно-дорожній університет
}

Постановка проблеми. Ключовими особливостями сучасного етапу розвитку суспільства виступає формування інноваційної економіки, підгрунтям якої стає якісна система вищої освіти та можливість застосування отриманих знань задля набуття стійких конкурентних переваг в перспективі, а процес формування використовує новий інструментарій 3 «соціально-орієнтованою компонентою» та розвиває відносини освіти, суспільства і бізнеса на партнерських засадах.

Сьогодні соціальна відповідальність постає інноваційним вектором на шляху інтеграції системи вищої освіти та діяльності господарських суб'єктів.

Перехід національної економіки на інноваційний шлях розвитку в ситуації економічної та демографічної кризи водночас загострює проблему якості підготовки фахівців, як однієї 3 головних умов набуття конкурентоспроможності закладами вищої освіти, та вимагає принципових змін освітньої політики щодо процесу практико-орієнтованої професійної підготовки кадрів.

Інноваційна освітня політика має бути спрямована на реалізацію інноваційних освітніх програм та забезпечення ринку праці сучасним поколінням економічно і інноваційно обізнаних фахівців, рівень професійних компетенцій яких би задовольнив всі вищезгадані зацікавлені сторони. При цьому розвиток такого типу пов'язаний не тільки з управлінням новаціями, а й розумінням необхідності постійної роботи по створенню бажаних умов для таких змін та посиленню адаптаційних якостей.

Все це вимагає від системи вищої освіти, будучи важливим соціальним інститутом, нести соціальну відповідальність та вирішувати багатоаспектні задачі: наукові, економічні, соціальні, культурні та ін.

Аналіз останніх досліджень і публікацій. Соціальна відповідальність закладу вищої освіти - це додаткові (поза межами освітніх послуг) соціально орієнтовані зобов'язання, що грунтуються на етичних та правових нормах, сприяють розвитку внутрішнього та зовнішнього середовища, враховуючи інтереси всіх зацікавлених сторін «освіта-бізнес-суспільство»), дотримуються стратегічних інтересів та несуть відповідальність за соціально-економічні наслідки своєї діяльності. Одним з основних засобів формування сучасного 
ринкового мислення є рівень економічної освіти, який орієнтований на все населення та підкріплений цілою системою інститутів, форм i методів отримання громадянами економічних знань, умінь і навичок, необхідних для їх ефективної соціально-активної діяльності [1].

Реалії сьогодення обумовлюють потребу інтеграції освіти, науки, держави та бізнесу, тим самим активізуючи інноваційну діяльність на кожному рівні та підсилюючи значущість саме вищої школи, яка має нести соціальну відповідальність за ефективне використання [2]:

- суспільних/державних ресурсів 3 метою підвищення ефективності роботи вищих навчальних закладів, забезпечення єдності навчання і виховання, залучення студентів та викладачів у різні соціальні практики;

- власних ресурсів - для розвитку і консолідації суспільства, проведення демократичних реформ;

- взаємодії 3 окремими громадянами, органами влади, бізнесструктурами, різними організаціями та установами - для функціонування вищих навчальних закладів як соціального інституту відкритого типу, центру соціальної політики в регіоні його присутності.

Під соціальною відповідальністю вищої освіти розуміється відповідальність вищих навчальних закладів, зокрема, університетів як соціального інституту перед суспільством за результати і якість своєї професійної діяльності [3].

Соціально - відповідальна діяльність освіти як суб'єкта надання освітніх послуг, а закладів освіти - як організацій, що є суб'єктами ринку освітніх послуг, виконує наступні завдання: соціальна відповідальність щодо працівників навчально-виховних і освітніх закладів; соціальна відповідальність у відносинах зі споживачами (учні, батьки, студентство, роботодавці тощо); ведення основної діяльності закладу освіти відповідно до концепції корпоративної соціальної відповідальності; дотримання принципів добросовісної конкуренції, соціально відповідальний маркетинг; етична поведінка закладу щодо контрагентів; розвиток партнерства 3 місцевою владою та громадою, співпраця 3 неурядовими організаціями; відповідальне ставлення до довкілля [4].

Проте основними проблемами розвитку вищої освіти як складової частини загальної освітньої системи наразі залишаються: надлишок (масовізація) обсягу пропозиції послуг вищої освіти на ринку та дисбаланс на ринку праці; інтернаціоналізація; фінансова криза університетської освіти i пошук шляхів виходу 3 неї; диверсифікація вищих навчальних закладів; наявність проблем в системі забезпечення якості вищої освіти; недостатній рівень новітніх технологій навчання; проблема відкритості та конкурентоспроможності університетів; вирівнювання національних освітніх систем i роль університету в цьому процесі; потреба в удосконаленні управління; соціальна відповідальність університетів [5]. 
Невирішені складові загальної проблеми. Динамічні ринкові відносини вимагають від сучасної освітньої системи реалізації моделі інноваційного освітнього процесу практико-орієнтованої професійної підготовки фахівців 3 перенесенням вектору «викладач - дисципліна» на «здобувач освіти професійні компетенції». Тобто технологія та програма професійної підготовки має системно модернізуватися, як за змістом, так і за аспектами забезпечення якості, за умови забезпечення реалізації комплексу певних педагогічних умов.

Водночас наявні передумови для модернізації системи вищої освіти та формування нових державних освітніх стандартів мають сприяти тому, що всі учасники взаємовідносин «освіта-бізнес-суспільство» повинні бути соціально відповідальними у вирішенні виникаючих проблем.

Формулювання цілей статті. Метою статті є обгрунтування моделі інноваційного освітнього процесу практико-орієнтованої підготовки фахівця, як соціально орієнтованої особистості з високим рівнем не тільки обов'язкових професійних компетенцій (навчальна i дослідницька компонента), але й інноваційно орієнтованого з підприємницькими здібностями.

Виклад основного матеріалу дослідження. Сучасний менеджмент виокремлює соціальну відповідальність як один 3 інструментів розвитку суспільства, основні принципи якого реалізуються в співпраці освіти, суспільства та бізнес-середовища, а зона відповідальності набуває нових факторів неекономічного характеру, які фокусуються на аспектах соціальної значущості [6-9].

Вища освіта має бути соціально відповідальною для покращення нашого розуміння багатогранних проблем, які включають соціальний, економічний, науковий і культурний виміри, а також нашу здатність відповідати їм. Вона повинна привести суспільство до створення глобальних знань, які б відповідали глобальним викликам, між іншим викликам продовольчої безпеки, зміни клімату, розподілу водних ресурсів, міжкультурного діалогу, запровадження відтворювальних джерел енергії та охорони здоров'я [10].

В свою чергу, в розвинутій країні напрями реалізації соціальної відповідальності освіти мають сприяти розмиванню соціальних бар'єрів в суспільстві, поширенню знань 3 соціальної відповідальності, а також активізувати наукову та виробничу співпрацю з бізнесом та ін. [10].

Сучасний заклад вищої освіти повинен забезпечувати підготовку фахівців 3 прекрасними професійними та діловими якостями, здібностями до управлінської діяльності та прийняття інноваційних рішень.

Саме тому модель інноваційного освітнього процесу професійної практико-орієнтованої підготовки фахівців має бути цілісною багаторівневою структурно-функціональною педагогічною системою, яка поєднає елементи загальної та професійної освіти, а також забезпечить виховання соціальноорієнтованого фахівця.

Ефективне функціонування даної системи та професійна підготовка фахівців мають забезпечуватися виконанням комплексу педагогічних умов, що 
відповідають запитам з боку суспільного виробництва, сфери бізнесу та очікуваних соціальних наслідків:

- педагогічне сприяння підготовці i вихованню соціально орієнтованої особистості (ділової людини 3 креативним баченням i прогресивним економічним мисленням);

- педагогічна допомога в розвитку підприємницьких здібностей як інтегрованих професійно-трудових та соціально-економічних якостей фахівця сфери бізнесу;

- в використання технологій психології/педагогіки задля особистісного та професійного розвитку майбутнього фахівця, а також досягнення бажаного результату професійної підготовки;

- забезпечення постійного підвищення кваліфікації професорськовикладацького персоналу за вимогою моделі практико-орієнтованої професійної підготовки фахівців;

- сприяння інноваційно-педагогічної діяльності та впровадження нових концептуальних засад в освітній процес;

- $\quad$ орієнтація на довгострокові взаємовигідні відносини з промисловим сектором та сприяння активній сумісній реалізації перспективних соціальних проектів.

Освітнє середовище є відкритою педагогічною системою, що напряму приймає участь у формуванні особистісних якостей та професійних компетенцій майбутнього фахівця, а тому й несе повну солідарну соціальну відповідальність за результат його підготовки та виховання соціально орієнтованої особистості, чим забезпечує собі набуття конкурентних переваг.

Довгостроковість набутої конкурентної переваги соціально відповідальної організації в подальшому має забезпечуватися якісним управлінням, ефективними психолого-педагогічними технологіями, прийняттям соціально-орієнтованих управлінських рішень 3 подальшою їх імплементацією в систему управління конкурентоспроможністю.

Висновки 3 проведеного дослідження. Реалізація практико-орієнтованої професійної підготовки фахівців пов'язана з освоєнням нової концепції в освітній діяльності, нового змісту та інноваційної форми педагогічної роботи на засадах соціальної відповідальності. Модель інноваційного освітнього процесу має використовувати єдність взаємодіючих елементів (підсистем): цільовий, нормативний, організаційний та результативний, які б сприяли всебічному формуванню сучасного ринкового мислення майбутнього фахівця та його свідомості щодо соціальної відповідальності.

\section{Перелік посилань}

1. Кирчата I. M., Шершенюк О. М. Забезпечення конкуренто спроможності закладу вищої освіти в контексті соціальної відповідальності. Проблеми і перспективи розвитку підприємництва : Збірник наукових прачь Харківського національного автомобільно-дорожнього університету. № 1 (24). 2020. C.80-90. 
2. Кузьмін О. Є., Пирог О. В., Чернобай Л. І., Романишин С. Б., Вацик Н. О. Соціальна відповідальність: навч. посібник. Львів, 2016. 328 с.

3. Калінеску Т. В., Ліхоносова Г. С., Альошкін В. С.. Соціальна відповідальність: підручник. Сєвєродонецьк, 2015. 472 с. : сайт URL: https://pidruchniki.com/73476/sotsiologiya/ sotsialnvidpovidalnist osviti_nauki.

4. Іванова І. В. Ушакова Н. М. Проактивна позиція освіти в реалізації соціальної відповідальності. Вчені записки Університету «КРОК»: зб. наук. праџь. К. : Університет економіки і права «КРОК», 2011. С.134-141.

5. Поляков М. В., Савчук В.С. Класичний університет : еволюція, сучасний стан, перспективи. Київ, 2004. 416 с.

6. Буян О. Я. Підходи до оцінки ефективності корпоративної соціальної відповідальності підприємств в Україні. Вісник Дніпропетровського університету. Серія «Економіка». 2012. Вип. 6 (2). С. 159-165.

7. Зінченко А. Г. Корпоративна соціальна відповідальність 2005-2010 : стан та перспективи розвитку. Київ, 2010. 56 с.

8. Лупак Р. Л. Соціальна відповідальність як складова забезпечення конкурентоспроможності підприємства. Соціально-трудові відносини: теорія та практика. 2016. № 2. С. 98-103.

9. Мазуренко В. П. Сучасна концепція корпоративної соціальної відповідальності у міжнародному бізнесі. Ефективна економіка. 2012. № 6. : сайт URL: http://nbuv.gov.ua/UJRN/efek_2012_6_17.

10. Орлова Н. С., Харламова А. О. Концептуальні засади корпоративної соціальної відповідальності в Україні : монографія. Донецьк, 2014. 250 с.

\section{References}

1. Kyrchata, I. M., Shershenyuk, O. M. (2020), „Ensuring the competitiveness of higher education institutions in the context of social responsibility" ["Zabezpechennia konkurentospromozhnosti zakladu vyshchoi osvity v konteksti sotsialnoi vidpovidalnosti"], Problems and perspectives of entrepreneurship development: Collection of scientific works of Kharkiv National Automobile and Road University, № 1 (24), P.80-90.

2. Kuzmin, O. Ye., Pyroh, O. V., Chernobai, L. I., Romanyshyn, S. B., Vatsyk, N. O. (2016), ,Social responsibility” [Sotsial'na vidpovidal'nist'], Lviv, 328 p.

3. Kalinesku, T. V., Likhonosova, H. S., Aloshkin, V. S. (2015), „Social responsibility" [Sotsial'na vidpovidal'nist'], Sievierodonetsk, 472 p., available at : https://pidruchniki.com/73476/ sotsiologiya / sotsialna vidpovidalnist osviti_nauki.

4. Ivanova, I. V. Ushakova, N. M. (2011), „Proactive position of education in the implementation of social responsibility" ["Proaktyvna pozytsiia osvity v realizatsii cotsialnoi vidpovidalnosti"], Scientific notes of the University "KROK": coll. Science. wash. K.: University of Economics and Law "KROK", P.134-141

5. Polyakov, M.V., Savchuk, V.S. (2004), Classical University: evolution, current state, prospects [Klasychnyi universytet : evoliutsiia, suchasnyi stan, perspektyvy], Kiev, 416 p.

6. Buyan, O. Ya. (2012), "Approaches to the assessment of the effectiveness of 
corporate social responsibility in Ukraine" ["Pidhodi do ocinki efektivnosti korporativnoï social'noï vidpovidal'nosti pidpriemstv v Ukraïni"], Bulletin of Dnipropetrovsk University. Economics Series, No 6 (2), P.159-165.

7. Zinchenko, A. G. (2010), Corporate Social Responsibility 2005-2010: Status and Prospects for Development [Korporatyvna sotsialna vidpovidal'nist' 2005-2010 $\therefore$ stan ta perspektyvy rozvytku], Kiev, $56 \mathrm{p}$.

8. Lupak, R. L. (2016), "Social responsibility as a component of ensuring the competitiveness of an enterprise" ["Sotsial'na vidpovidal'nist' yak skladova zabezpechennya konkurentospromozhnosti pidpryyemstva"], Social-labor relations: theory and practice, No. 2, P. 98-103.

9. Mazurenko, V. P. (2012), "The Modern Concept of Corporate Social Responsibility in International Business" ["Suchasna kontseptsiya korporatyvnoyi sotsialnoyi vidpovidal'nosti u mizhnarodnomu biznesi"], Effective Economy, No. 6, available at : http://nbuv.gov.ua/UJRN/efek_2012_6_17.

10. Orlova, N. S., Kharlamova, A. A. (2014), Conceptual principles of corporate social responsibility in Ukraine [Kontseptualni zasady korporatyvnoi sotsialnoi vidpovidalnosti v Ukraini ], Monograph, Donetsk, 250 p.

\section{РЕФЕРАТИ РЕФЕРАТЫ ABSTRACTS}

\section{УДК 338.242; JEL Classification: M14}

Кирчата І.М., Шершенюк О.М. СОЦІАЛЬНА ВІДПОВІДАЛЬНІСТЬ ЯК СКЛАДОВА ІННОВАЦІЙНОГО ОСВІТНЬОГО ПРОЦЕСУ ТА ЗАБЕЗПЕЧЕННЯ КОНКУРЕНТОСПРОМОЖНОСТІ ЗАКЛАДУ ВИЩОЇ ОСВІТИ

Мета - обгрунтування моделі інноваційного освітнього процесу практико-орієнтованої підготовки фахівця, як соціально орієнтованої особистості з високим рівнем не тільки обов'язкових професійних компетенцій (навчальна і дослідницька компонента), але й інноваційно орієнтованого 3 підприємницькими здібностями. Методика дослідження. Теоретичною i методологічною основою $є$ праці провідних вітчизняних і зарубіжних ученихекономістів, в яких розглядається соціальна відповідальність в контексті забезпечення конкурентоспроможності закладів вищої освіти через партнерські відносини «освіта-суспільство-бізнес». Використано методи узагальнення та абстрагування; метод аналізу і синтезу. Результати. Динамічні ринкові відносини вимагають від сучасної освітньої системи реалізації моделі інноваційного освітнього процесу практико-орієнтованої професійної підготовки фахівців 3 перенесенням вектору «викладач - дисципліна» на «здобувач освіти-професійні компетенції». Тобто технологія та програма професійної підготовки має системно модернізуватися, як за змістом, так і за аспектами забезпечення якості, за умови забезпечення реалізації комплексу 
певних педагогічних умов. Ефективне функціонування даної системи та професійна підготовка фахівців повинні забезпечуватися виконанням комплексу педагогічних умов, що відповідають запитам з боку суспільного виробництва, сфери бізнесу та очікуваних соціальних наслідків. Модель інноваційного освітнього процесу має використовувати єдність взаємодіючих елементів (підсистем): цільовий, нормативний, організаційний та результативний, які б сприяли всебічному формуванню сучасного ринкового мислення майбутнього фахівця та його свідомості щодо соціальної відповідальності. Наукова новизна. В роботі теоретично обгрунтовано доцільність використання моделі інноваційного освітнього процесу професійної практико-орієнтованої підготовки фахівців, яка має бути цілісною багаторівневою структурно-функціональною педагогічною системою, поєднувати елементи загальної та професійної освіти, а також забезпечувати виховання соціально-орієнтованого фахівця. В такій моделі соціальна відповідальність виступає своєрідним інноваційним вектором розвитку системи вищої освіти, сприяє набуттю високого рівня не тільки традиційних професійних компетенцій, але й особистісних якостей майбутнього фахівця. Практична значущість. Практична реалізація практико-орієнтованої професійної підготовки фахівців пов’язана 3 освоєнням нової концепції в освітній діяльності, нового змісту та інноваційної форми педагогічної роботи на засадах соціальної відповідальності. Заклад вищої освіти несе в даному випадку повну солідарну соціальну відповідальність за результат підготовки та виховання соціально орієнтованої особистості, чим забезпечує собі набуття конкурентних переваг на майбутнє.

Ключові слова: вища освіта; соціальна відповідальність; конкурентоспроможність; конкурентна стійкість; соціальні відносини

УДК 338.242; JEL Classification: M14

Кирчатая И.Н., Шершенюк Е.Н. СОЦИАЛЬНАЯ ОТВЕТСТВЕННОСТЬ КАК СОСТАВЛЯЮЩАЯ ИННОВАЦИОННОГО ОБРАЗОВАТЕЛЬНОГО ПРОЦЕССА И ОБЕСПЕЧЕНИЯ КОНКУРЕНТОСПОСОБНОСТИ ВЫСШЕГО УЧЕБНОГО ЗАВЕДЕНИЯ

Цель - обоснование модели инновационного образовательного процесса практико-ориентированной подготовки специалиста, как социально ориентированной личности с высоким уровнем не только обязательных профессиональных компетенций (учебная и исследовательская компонента), но и инновационно ориентированного с предпринимательскими способностями. Методика исследования. Теоретической и методологической основой являются труды ведущих отечественных и зарубежных ученых-экономистов, в которых рассматривается социальная ответственность в контексте обеспечения конкурентоспособности высших учебных заведений через партнерские отношения «образование-общество-бизнес». Использованы методы обобщения 
и абстрагирования; метод анализа и синтеза. Результаты. Динамичные рыночные отношения требуют от современной системы образования реализации модели инновационного образовательного процесса практикоориентированной профессиональной подготовки специалистов с перенаправлением вектора «преподаватель - дисциплина» на «соискатель образования - профессиональные компетенции». Поэтому технология и программа профессиональной подготовки должна системно модернизироваться, как по содержанию, так и по аспектам качества, при условии обеспечения реализации комплекса определенных педагогических условий. Эффективное функционирование данной системы и профессиональная подготовка специалистов должны обеспечиваться выполнением комплекса педагогических условий, отвечающих запросам со стороны общественного производства, сферы бизнеса и ожидаемых социальных последствий. Модель инновационного образовательного процесса должна использовать единство взаимодействующих элементов (подсистем): целевой, нормативный, организационный и результативный, способствующих всестороннему формированию современного рыночного мышления будущего специалиста и его осознанной социальной ответственности. Научная новизна. В работе теоретически обоснована целесообразность использования модели инновационного образовательного процесса профессиональной практикоориентированной подготовки специалистов, которая должна быть целостной многоуровневой структурно-функциональной педагогической системой, сочетать элементы общего и профессионального образования, а также обеспечивать воспитание социально-ориентированного специалиста. В такой модели социальная ответственность выступает своеобразным инновационным вектором развития системы высшего образования, способствует приобретению высокого уровня не только традиционных профессиональных компетенций, но и личностных качеств будущего специалиста. Практическая значимость. Практическая реализация практико-ориентированной профессиональной подготовки специалистов связана с освоением новой концепции в образовательной деятельности, нового содержания и инновационной формы педагогической работы на принципах социальной ответственности. Высшее учебное заведение несет в данном случае полную солидарную социальную ответственность за результат подготовки и воспитания социально ориентированной личности, чем обеспечивает себе приобретение конкурентных преимуществ в будущем.

Ключевые слова: высшее образование; социальная ответственность; конкурентоспособность; конкурентная устойчивость; социальные отношения. 


\section{UDC 338.242; JEL Classification: M14}

Kyrchata I. M., Shershenyuk E. N. SOCIAL RESPONSIBILITY AS A COMPONENT OF THE INNOVATIVE EDUCATIONAL PROCESS AND ENSURING THE COMPETITIVENESS OF THE HIGHER EDUCATION INSTITUTION

The purpose is to substantiate the model of innovative educational process of practice-oriented training as a socially oriented person with a high level of not only mandatory professional competencies (educational and research component), but also innovation-oriented with entrepreneurial skills. Methodology of research. The theoretical and methodological basis is the work of leading domestic and foreign economists, which are considered social responsibility in the context of ensuring the competitiveness of higher education institutions through partnerships "educationsociety-business". Methods of generalization and abstraction are used; method of analysis and synthesis. Findings. Dynamic market relations require the modern educational system to implement a model of innovative educational process of practice-oriented professional training with the transfer of the vector "teacher discipline" to "student-professional competencies". That is, the technology and training program should be systematically modernized, both in terms of content and aspects of quality assurance, provided that the implementation of a set of certain pedagogical conditions. The effective functioning of this system and professional training should be ensured by the implementation of a set of pedagogical conditions that meet the demands of social production, business and the expected social consequences. The model of innovative educational process should use the unity of interacting elements (subsystems): objective, normative, organizational and effective, which would contribute to the comprehensive formation of modern market thinking of the future specialist and his awareness of social responsibility. Originality. The paper theoretically substantiates the feasibility of using the model of innovative educational process of professional practice-oriented training, which should be a holistic multilevel structural and functional pedagogical system, combine elements of general and professional education, as well as provide education for socially oriented professionals. In this model, social responsibility is a kind of innovative vector for the development of higher education, contributes to the acquisition of a high level of not only traditional professional competencies, but also the personal qualities of the future specialist. Practical value. The practical implementation of practice-oriented professional training is associated with the development of a new concept in educational activities, new content and innovative forms of pedagogical work on the basis of social responsibility. In this case, the higher education institution bears full joint several social responsibility for the result of training and education of a socially oriented individual, which ensures the acquisition of competitive advantages for the future.

Key words: higher education; social responsibility; competitiveness; competitive stability; social relations 


\section{Відомості про авторів / Сведения об авторах / About the Authors}

Кирчата Ірина Миколаївна - кандидат економічних наук, доцент, Харківський національний автомобільно-дорожній університет, доцент кафедри економіки i підприємництва, м. Харків, Україна; e-mail: kirchatayairina@gmail.com; ORCID ID: https://orcid.org/0000-0002-0270-1586. Моб. 0506690096.

Кирчатая Ирина Николаевна - кандидат экономических наук, доцент, Харьковский национальный автомобильно-дорожный университет, доцент кафедры экономики и предпринимательства, г.Харьков, Украина.

Kyrchata Iryna Mykolayivna - Candidate of Science (Economics), Associate Professor, Kharkiv National Automobile and Highway University, Associate Professor, Department of Economics and Entrepreneurship, Kharkiv, Ukraine.

Шершенюк Олена Миколаївна - кандидат економічних наук, доцент, Харківський національний автомобільно-дорожній університет, доцент кафедри економіки і підприємництва, м. Харків, Україна; e-mail: sheralyona@gmail.com; ORCIDID: https://orcid.org/0000-0002-9959-2725. Моб. 0501513009.

Шершенюк Елена Николаевна - кандидат экономических наук, доцент, Харьковский национальный автомобильно-дорожный университет, доцент кафедры экономики и предпринимательства, г. Харьков, Украина.

Shershenyuk Elena Nikolaevna - Candidate of Science (Economics), Associate Professor, Kharkiv National Automobile and Highway University, Associate Professor, Department of Economics and Entrepreneurship, Kharkiv, Ukraine. 